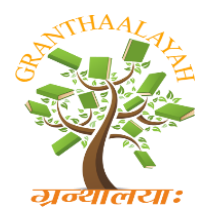
\author{
GRANTHAALAYAH \\ A knowledge Repository
}

INTERNATIONAL JOURNAL OF RESEARCH -

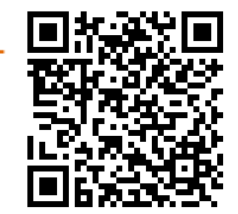

Science

\title{
PHYSIOLOGICAL CHARACTERIZATION OF SIX WHEAT GENOTYPES FOR DROUGHT TOLERANCE
}

\author{
Muhammad Hanif Chachar ${ }^{* 1}$, Nazir Ahmed Chachar ${ }^{* 2}$, Qamaruddin Chachar ${ }^{3}$, \\ Sheikh Muhammad Mujtaba ${ }^{4}$, Sadaruddin Chachar ${ }^{5}$, Zaid Chachar ${ }^{6}$ \\ ${ }^{*} 1,3,6$ Department of Crop Physiology, Sindh Agriculture University, Tandojam, PAKISTAN \\ ${ }^{*}$ College of Agronomy and Biotechnology, China Agricultural University, Beijing, P.R. \\ CHINA \\ ${ }^{4}$ Plant Physiology Division, Nuclear Institute of Agriculture (NIA) Tandojam, PAKISTAN \\ ${ }^{5}$ Institute of Crop Biotechnology, Chinese Academy of Agriculture Sciences, Beijing, CHINA
}

\begin{abstract}
Pakistan is one of the most severely affected countries by Global climate change, it is an agriculture based country and its economy (21\%) mainly depend on agriculture production. Wheat is the major staple food crop in Pakistan and takes key position in the national economy. It contribute $12.5 \%$ share in agriculture and $2.9 \%$ in the country's GDP. Frequent droughts and scarcity of the water severely affecting the wheat production. To fulfill the feed requirements of rapidly growing population, it is necessary to explore the advanced genetic resource that can be able to perform better in changing climate. Six wheat genotypes were tested for their early seedling and physiological performance under different water stress environments. The seeds of six wheat genotypes (Khirman, Chakwal-86, MSH-36, DH-3/48, NIA Amber and NIA-10 10/8) were tested for physiological characterization under pot house experiment for individual genotypic response to water stress. The variance of analysis shows two-way interaction water stress [Control (normal four irrigations) and terminal drought (Soaking dose) and wheat genotypes (P $\leq 0.05)$. Seven physiological indices, including Proline content, Glycine-betaine, Total sugars, Total chlorophyll, Nitrate Reductase Activity ((NRA), Potassium $(\mathrm{K}+)$ content, and Osmotic potential $(\mathrm{OP})$ were used to evaluate the drought tolerance of six wheat genotypes. From the current data it was illustrated that, MSH-36 and DH-3/48 exhibited the tolerance followed by, Khirman and Chakwal-86 by maintaining their osmotic potential and accumulation of higher proline and glycine-betaine content that helpful for plant to enhancing their tolerance under water stress and to maintain their growth and development, whereas NIA Amber and NIA-10 10/8 are the drought sensitive genotypes as they could not maintain their osmotic potential under drought stress environment.
\end{abstract}

Keywords:

wheat, osmotic stress, drought tolerance, physiological response.

Cite This Article: Muhammad Hanif Chachar, Nazir Ahmed Chachar, Qamaruddin Chachar, 
Sheikh Muhammad Mujtaba, Sadaruddin Chachar, and Zaid Chachar, "PHYSIOLOGICAL CHARACTERIZATION OF SIX WHEAT GENOTYPES FOR DROUGHT TOLERANCE" International Journal of Research - Granthaalayah, Vol. 4, No. 2 (2016): 184-196.

\section{INTRODUCTION}

Pakistan is an agriculture based country and its economy (about 21\%) is mainly relying on agriculture production; however, it is confronting the problem of water shortage, because the average rainfall in country is less than $240 \mathrm{~mm}$ a year as reported by Ahmed et al., (2008) which is revealing an adverse impact on food security. According to Harmeling and Eckstein, (2013), that Pakistan is ranked at $8^{\text {th }}$ position in most affected countries by the effects of climate change on climate risk index 1992-2011. Despite its contribution to greenhouse gas (GHG) emissions is diminutive in comparison with other countries (it only adds about $0.8 \%$ of the total GHG emissions), it is one of the major victims of the adverse effects of climate change. The severity of these negative effects is higher for the Agriculture sector as compared to manufacturing and services (Akram and Hamid. 2015), moreover major destructive impacts of these climatic changes will be frequent and severe droughts and it is great challenge for crop scientists, especially for plant breeders, to develop new cultivars and hybrids of major crops that will be able to acclimate to the changing climate (Waggoner, 1993). Pakistan is one of the major wheat (Triticum aestivum L.) producer in the world and ranked $9^{\text {th }}$ in wheat grain production (Anon., 2000). Wheat is the major staple food crop and take a key position in the agricultural policies of the Pakistan. Since wheat production declined to 25,478 thousand tonnes during growing year 2014-15 as compared to 25,979 thousand tonnes in 2013-14 which reveals 1.9 percent decline in annual wheat production (Anonymous 2015). The average grain yield in Pakistan is relatively lower. The main reason of low grain productivity is the scarcity of water (Ashraf, 1998). Food insecurity is a crucial and greater hindrance to social and economic development of the country and needs critical scientific inquiry, and idea of viewing this issue in terms of climate change carries with its multipronged strategy to address the issue seriously.

Drought stress causes different biochemical, molecular, physiological and morphological changes in the plants that may cause retardation of plant growth and developmental processes, effect of these changes is dependent on the time, stage and severity of water stress (Cao et al. 2011). Water stress results in loss of water within the plant and result in relative water content declines. Therefore, relative water content is widely used as one of the most reliable tool for characterization of both the sensitivity and the tolerance of plants to water stress (Rampino et al. 2006; Sanchez-Rodriguez et al. 2010). Plants naturally synthesize some sort of compatible organic substances such as glycine-betaine, proline and polyols in the cytosol to increase osmotic pressure and therefore to regulate both turgor and driving gradient for water absorption from the soil (Rhodes \& Samaras 1994) and to protect cellular membranes and proteins from oxidative damage (Delauney \& Verma 1993). It has been shown that under high osmotic stress proline content plays a vital role to protect cellular membranes by damaging effect of reactive oxygen species and maintain and proteins contents (Errabii et al. 2006). It is reported that the accumulation of malon-di-aldehyde (MDA), under oxidative stress is a by-product of fatty acid peroxidation, synthesized by cellular membrane lipid peroxidation in different plant species during oxidative stress. 
Plants demonstrating high water stress tolerance are the most suitable object of drought-related investigation and are the most auspicious sources of drought related gene, such type of gene can be utilized in the development of modern desirable crop cultivars. These comprise the natural originators of cultivated crops and for wheat development, Ae. tauschii, which is more water stress tolerant genotype as compare to Triticum and Wild emmer wheat (T.dicoccoides), its harbors water stress tolerance characteristics vanished during cultivation of modern wheat cultivars (Ashraf et al. 2009). Consequently the genetically improved cultivars for water stress tolerance has been a principal objective of the majority of breeding programmes for a long time because water stress during different growth stages of wheat is common in wheat growing areas of the world (Moustafa et al., 1996). The ability of a crop plant to produce maximum harvest over a wide range of stress and non-stress conditions is very important. Plants tolerate under stress environment at the cost of yield to survive with this circumstance the yield losses should be decreased earlier reported by Ahmad et al., (2006). So, exploration of drought tolerant genes among available gene pool is of great importance in wheat breeding program in order to improve the crop ability to produce good harvest under abiotic stress environment. The main object of this study to identification and functional characterization of drought tolerance indices such as, Nitrate Reductase activity (NRA) Potassium $\left(\mathrm{K}^{+}\right)$uptake, free proline, Glycine-betaine, total soluble sugars, chlorophyll and osmotic potential content. These indices extensively used to assess plant drought tolerance under water stress conditions.

\section{MATERIALS AND METHOD}

The current studies were conducted at Plant Physiology Division of Nuclear Institute of Agriculture (NIA), Tandojam. The experiment was conducted in the Pot house. Six wheat genotypes were tested for their physiological performance for drought tolerance under controlled cemented tanks (size 3x3x1 cubic meter), filled with sandy clay loam soil. Two drought tolerant genotypes i.e., Chakwal-86 and Khirman were also included as local check as compare among the genotypes under control (normal four irrigations) and Terminal drought (T. Drought) conditions. The experiment was laid out in Complete Randomize Block Design (CRBD) with three replications. The spacing between row-row and plant-plant were $0.5 \times 0.06$ meter. Nitrogen and phosphorous fertilizers were applied in the form of urea @ $120 \mathrm{~kg} \mathrm{ha}^{-1}$ and DAP (Di Ammonium Phosphate) @ $70 \mathrm{~kg} \mathrm{P}_{2} \mathrm{O}_{5} \mathrm{ha}^{-1}$ at surface prior to sowing. Drought treatment was imposed in four cemented tanks by withholding irrigation water after sowing, whereas control plots were irrigated normally (four irrigations). Soil moisture content was monitored regularly till harvesting.

Proline content ( $\mu$ mol. $g^{-1}$ fresh weight)

Free proline content was measured ( $\mu$ mol. $\mathrm{g}^{-1}$ fresh weight), using the method elaborated by Bates et al., (1987).

Glycine-betaine ( $\mu$ mol. $g^{-1}$ fresh wt.)

Glycine-betaine was estimated by the method described by Grieve \& Gratan (1983).

Total Soluble Sugars ( $\mu$ mol. $g^{-1}$ fresh wt.)

Total Soluble Sugars (TSS) were determined from fresh leaves according to Riazi et al., (1985). 
Total chlorophyll ( $\mathrm{mg} \mathrm{g}^{-1}$ fresh $w t$.)

The chlorophyll was determined according to the method of Lichtenthaler (1987).

Nitrate Reductase Activity ((NRA) ( $\mu$ mol. $g^{-1}$ fresh wt. $\left.h r^{-1}\right)$

Nitrate Reductase Activity (NRA) in flag leaves was recorded using the method of Sym (1983).

Potassium $\left(K^{+}\right)$content (\% $g^{-1}$ fresh $\left.w t.\right)$

Potassium contents were measured in percentage $\left(\% \mathrm{~g}^{-1}\right.$ fresh weight $)$ using method elaborated by Flowers (1986).

Osmotic potential (-MPa)

The osmotic potential of leaves was determined using the Shardakov method (Slavik, 1974).

Statistical analysis

The data recorded were subjected to analysis of variance to discriminate the superiority of treatment means and LSD test were applied by the following method of Gomez and Gomez (1984) to compare the means.

\section{RESULT}

\subsection{Proline content ( $\mu$ mol. $g^{-1}$ fresh wt.)}

In the present studies, we found that water stress caused a significant $(\mathrm{p}<0.05)$ increase in the free proline content. Under the control level (Normal four irrigations) wheat genotype MSH-36 content maximum free proline concentration $\left(9.62 \mathrm{mmol} \mathrm{g}^{-1}\right.$ fresh wt.), whereas lowest free proline were recorded in DH-3/48, NIA-10 10/8, and Chakwal86 $\left(6.44,6.29\right.$ and $6.45 \mathrm{mmol} \mathrm{g}^{-1}$ fresh wt.) as shown in figure-1. Although the genotypes NIA Amber and Khirman shown lowest concentration of free proline content (5.79 and $4.25 \mathrm{mmol} \mathrm{g}^{-1}$ fresh wt.) under control level. Although the crop grown under drought stress (Terminal Drought/ soaking dose) all the wheat genotypes exhibited higher accumulation of free proline content in the flag leaf. A great variation in free proline content were found among the genotypes. Chakwal-86 accumulate higher amount of free proline (123.3 mmol g${ }^{-1}$ fresh wt.), followed by the DH-3/48 and Khirman (152.4 and $125.4 \mathrm{mmol} \mathrm{g}^{-1}$ fresh wt.), while the lowest free proline content were recorded in NIA Amber (69.35 mmol g-1 fresh wt.) respectively.

\subsection{Glycine-betaine ( $\mu$ mol. $g^{-1}$ fresh wt.)}

Accumulation of Glycine-betaine, free proline and potassium $(\mathrm{K})$ in the plant is one of most adaptive trait to cope with environmental stresses (Drought, heat, salt). Higher accumulation of Glycine-betaine help to enhance the tolerance of plant in ameliorating the effect of water stress on growth and development.

In the present studies we found that water stress caused a significant $(\mathrm{p}<0.05)$ for higher accumulation of Glycine-betaine content in flag leaf (Fig. 2). At control level maximum Glycinebetaine accumulation were recorded in NIA-10 10/8, Chakwal-86 and Khirman (37.1, 36.6 and 36.6 and $\mathrm{mmol} \mathrm{g}^{-1}$ fresh wt.), followed by DH-3/48 and NIA Amber (38.5 and $38.7 \mathrm{mmol} \mathrm{g}^{-1}$ 
fresh wt.), whereas the minimum accumulation of Glycine-betaine was recorded in MSH-36 (34.0 mmol g ${ }^{-1}$ fresh wt.), respectively. Great genotypic variation were found at terminal drought stress level, higher accumulation of Glycine-betaine were recorded in MSH-36 and Khirman (58.9 and $50.3 \mathrm{mmol} \mathrm{g}^{-1}$ fresh wt.), followed by DH-3/48 (82.8 $\mathrm{mmol} \mathrm{g}^{-1}$ fresh wt.), while the NIA-10 10/8, Chakwal-86 and NIA Amber accumulate lowest (45.3, 41.2 and $38.4 \mathrm{mmol} \mathrm{g}^{-1}$ fresh wt.), respectively.

\subsection{Total soluble sugars ( $\mu$ mol. $g^{-1}$ fresh wt.)}

The results of variance analysis signified that changes of flag leaf total soluble sugars content of genotypes and the treatments i.e. control (normal four irrigations) and water stress (terminal drought) were highly significant $(\mathrm{p}<0.05)$. The mean comparison of flag leaf total soluble sugar content in different wheat genotypes represent that Chakwal-86 and NIA10 10/8 (0.89 and 0.87 $\mu$ mol. $\mathrm{g}^{-1}$ fresh wt.) accumulate maximum total soluble sugars, followed by Khirman (1.07 $\mu$ mol. $\mathrm{g}^{-1}$ fresh wt.) at control level as presented in figure- 3. Meanwhile the minimum mean total sugars content at control level were recorded in DH-3/48 (0.79), MSH-36 (0.70) and NIA Amber $\left(0.55 \mu \mathrm{mol} . \mathrm{g}^{-1}\right.$ fresh wt. $)$ respectively. Under the terminal drought the highest total soluble sugar content were recorded in DH-3/48 (1.23), followed by the Khirman (1.55 $\mu$ mol. $\mathrm{g}^{-1}$ fresh wt.), whereas the lowest total soluble sugars content were recorded in Chakwal-86 (0.87), followed by NIA Amber (0.54 $\mu$ mol. $\mathrm{g}^{-1}$ fresh wt.) respectively.

\subsection{Total chlorophyll (mg $\mathrm{g}^{-1}$ fresh wt.)}

In the current studies decreasing trend was recorded with increase of water stress, as depicted in figure 4. Maximum mean values for total chlorophyll content was recorded at in control level (10.78 $\mathrm{mg} \mathrm{g}^{-1}$ fresh wt.), while higher reduction in mean total chlorophyll content in flag leaf was recorded in terminal drought stress $\left(8.00 \mathrm{mg} \mathrm{g}^{-1}\right.$ fresh wt. $)$. Genotypic variation were found in all wheat genotypes grown under control and terminal drought. Higher total chlorophyll content were recorded in MSH-36 (10.67) and Chakwal-86 (10.45 $\mathrm{mg} \mathrm{g}^{-1}$ fresh wt.), followed by Khirman (10.73 $\mathrm{mg} \mathrm{g}^{-1}$ fresh wt.), whereas the lowest total chlorophyll content were recorded in DH-3/48 (9.72) and NIA-10 10/8 (4.22), followed by NIA Amber (4.12 $\mathrm{mg} \mathrm{g}^{-1}$ ) at terminal drought level.

\subsection{Nitrate Reductase Activity (NRA) ( $\mu$ mol. $g^{-1}$ fresh wt. $\left.\mathrm{hr}^{-1}\right)$}

The results of variance analysis represented that Nitrate Reductase Activity (NRA) of genotypes and the treatments were highly significant $(\mathrm{p}<0.05)$. The NRA decreased with increasing water stress, maximum NRA were recorded at control level as compare to terminal drought (Fig.5). Maximal extractable NRA were recorded in Khirman and Chakwal-86 (1.75 and $1.73 \mu$ mol. $\mathrm{g}^{-1}$ fresh wt. hr ${ }^{-1}$ ), followed by, MSH-36 and DH-3/48 (1.92 and $1.77 \mu$ mol. $\mathrm{g}^{-1}$ fresh wt. hr ${ }^{-1}$ ) respectively, whereas the minimal NRA were recorded in genotype NIA-10 10/8 (0.59) followed by, NIA Amber $\left(1.15 \mu\right.$ mol. $\mathrm{g}^{-1}$ fresh wt. $\left.\mathrm{hr}^{-1}\right)$ respectively at terminal drought level. 


\subsection{Potassium $\left(\mathrm{K}^{+}\right)$content $\left(\% \mathrm{~g}^{-1}\right.$ fresh weight)}

The results of variance analysis revealed that flag leaf potassium content ( $\% \mathrm{~g}^{-1}$ fresh weight) of wheat genotypes and the treatments were highly significant $(\mathrm{p}<0.05)$. The potassium content was increased with increasing water stress, maximum potassium content in flag leaf was recorded at terminal drought (Fig.6). Mean potassium content in two treatments were recorded as terminal drought $\left(2.00 \% \mathrm{~g}^{-1}\right.$ fresh weight), while the lower potassium content $\left(1.46 \% \mathrm{~g}^{-1}\right.$ fresh weight) by wheat genotypes were recorded in non-stressed (control) level. Higher potassium content were revealed by the Khirman and Chakwal-86 (2.85and $2.55 \% \mathrm{~g}^{-1}$ fresh weight) followed by, the MSH-36 (2.93\% $\mathrm{g}^{-1}$ fresh weight), whereas lower potassium content were recorded from DH-3/48 (1.22\% $\mathrm{g}^{-1}$ fresh weight), followed by, NIA Amber $\left(0.79 \% \mathrm{~g}^{-1}\right.$ fresh weight) respectively under terminal drought.

\subsection{Leaf Osmotic potential (-MPa)}

The results of variance analysis revealed that osmotic potential (-MPa) of flag leaf of wheat genotypes and the treatments were highly significant $(\mathrm{p}<0.05)$. Increasing moisture stress had significant marked effect on the leaf osmotic potential content of all the wheat genotypes as shown in Figure 7. There was an increase in Osmotic potential (OP) content with increase in water stress in all wheat genotypes. The mean value for OP at terminal drought $(1.87-\mathrm{MPa})$ was higher as compared to control treatment (1.40 MPa). Under control treatment, Osmotic potential content was recorded maximum in genotype Khirman (1.68) and Chakwal-86 (1.74 -MPa) while the genotypes, DH-3/48 (1.64), MSH-36 (1.51), and NIA-10 10/8 (0.92 -MPa) had the intermediate osmotic potential content values. Meanwhile the minimum values for osmotic potential content were recorded in genotype NIA Amber $(0.77 \mathrm{MPa})$, respectively. The values depicted Osmotic potential at high water stress level (terminal drought), were recorded maximum in genotype Khirman (2.85 MPa) followed by, Chakwal-86 (2.68), DH-3/48 (2.41), MSH-36 (2.13), and NIA10 10/8 (1.44 MPa). Whereas minimum Osmotic potential content values were recorded in genotype NIA Amber $(0.90 \mathrm{MPa})$ at terminal drought level. The genotype Khirman, Chakwal-86, MSH-36 and DH-3/48 maintain their leave osmotic potential (OP) higher under terminal drought since they maintain higher relative water content.

\section{DISCUSSION}

\subsection{Proline content ( $\mu$ mol. $g^{-1}$ fresh weight)}

Plants are acclimatized under water deficit environment by osmoregulation for constant supply of water to plants under lower water potential and avoid dehydration (Moinuddin et al., 2005). Proline plays active role in osmoregulation and its accumulation increased more than ten times under drought as in the present study (Verslues and Sharma 2010, Minocha et al., 2014). Proline accumulation in plants could be very helpful in the drought injury sensor instead of its role in stress tolerance. Plant accumulates higher concentration of free proline in their leaves and other tissues while exposed to abiotic stress conditions (Tan \& Hollaran, 1982). Similar finding were also reported by other scientists (Sharpe and Verslues, 1999; Safarnejad et al, 1996; Staden et al, 1999; Mattioni, 1997; Serraj \& Sinclair, 2002). Prominent accumulation of proline might be act as a protective mechanism to maintaining protein structures and ROS at equilibrium level. 


\subsection{Glycine-betaine ( $\mu$ mol. $g^{-1}$ fresh wt.)}

Naturally accumulation of Glycine-betaine in organisms exposed to abiotic stress environment were earlier reported by Chen and Murata, 2002; Chen and Murata, 2008; Bohnert and Jensen, 1996. According to Monyo et al., (1992), plants are more tolerant that have greater ability to accumulate higher concentration of Glycinebetaine while grown under drought environment as compared with sensitive one. Plants naturally synthesize different kind of solutes such as proline, polyols and glycine-betaine, in the cytosol, Glycine betaine help in osmo-regulation under stress environment. It helps to maintain both turgor and driving gradient for water absorption as reported by Rhodes \& Samaras (1994) and to protect cellular membranes and proteins (Delauney \& Verma 1993).

\subsection{Total Soluble Sugars ( $\mu$ mol. $g^{-1}$ fresh wt.)}

The increase of total soluble sugars in plant may help to tolerate under drought stress as stated by Kameli \& Losel, (1993). The synthesis of osmotically active organic substances like soluble sugars, glycine-betaine, proline alcohols, and organic acids etc. is the ability of plant to adjust the external osmotic conditions and to maintain water balance under drought stress (Farooq et al., 2009; Mohammadkhani and Heidari, 2008). Water stress increases total soluble sugars accumulation has been earlier reported by different scientists in various crops such as rice (Mostajeran and Rahimi-Eichi, 2009) wheat (Akladious, 2012) and Soybean (Liu et al., 2011). Current studies validated these findings with an increase in total soluble sugars in terminal drought stressed wheat plants in comparison to well-watered what plants. The higher accumulation of total soluble sugars might be attributed to starch catabolism as a result of amylase activity under water stress (Ghasempour et al., 1998).

\subsection{Total chlorophyll ( $\mathrm{mg} \mathrm{g}^{-1}$ fresh wt.)}

Total chlorophyll content may be considered as an indication of dry matter accumulation and yield related traits with lowering oxidative damage (Zaharieva et al. 2001). Pigments contents, particularly chlorophylls are important to maintain photosynthetic activity in plant (Wright et al., 1994; Nageswara et al., 2001). Terminal drought stress inhibits photosynthesis by reducing chlorophyll contents (Chl) and affecting its synthesis, and damaging the photosynthetic organelles(chloroplast) of plants cells (Iturbe Ormaetxe et al., 1998). Drought stress reduces leaf Chl (Ommen et al., 1999) mainly due to damage to chloroplasts caused by the genesis of reactive oxygen species (ROS) (Smirnoff, 1995).Terminal drought caused decreased of chlorophyll content and protein content compared to normal irrigation levels (Moaveni, 2011; Almeselmani et al. 2012).

\subsection{Nitrate Reductase Activity ((NRA) ( $\mu$ mol. $g^{-1}$ fresh wt. $\left.h^{-1}\right)$}

There was a progressive correlation was recorded in relationship between total extractable NRA and the rate of photosynthetic $\mathrm{CO}_{2}$ integration such that the reduction of photosynthesis due to drought correlated with a marked decrease in total NRA. The NRA state reduction in terminal drought stressed leaves as compare to control. Former studies carried out by Kaiser et al., (1993) and Huber et al., (1996) stated that the reduction of $\mathrm{NO}_{3}{ }^{-}$to $\mathrm{NO}_{2}{ }^{-}$catalyzed by $\mathrm{NR}$, it could be 
accounted as the rate-limiting state of Nitrogen integration in flag leaf. NRA is corresponding with the fraction of photosynthesis and the accessibility of $\mathrm{C}$ skeletons by both transcriptional and posttranslational controls.

\subsection{Potassium $\left(\mathrm{K}^{+}\right)$content $\left(\% \mathrm{~g}^{-1}\right.$ fresh wt.)}

Plants utilize $\mathrm{K}^{+}, \mathrm{Na}^{+}$and $\mathrm{Ca}^{2+}$ for the regulation of turgor and cell membrane potential (Weyers and Paterson, 2001). The results of the present study revealed that the plants exposed to terminal drought stress content more $\mathrm{K}$ in shoot than the well-watered plants (Fig. 6). Different studies revealed an increase in $\mathrm{K}$ concentration in various crop species such as maize (Premachandra $e t$ al., 1991), wheat (Ashraf et al., 1998), pigeon pea (Ashraf, 1994) and sunflower (Iqbal et al., 2008) under drought stress. Potassium ions play a significant role during osmotic stress by regulating osmotic potential of the vacuoles even under severe water stress conditions (Marschner, 1995). Thus, application of potassium content fertilizers may helpful to maintain turgor pressure and osmotic adjustment that could be helpful to maintain lowering leaf water potentials and can enhance the ability of crop plants to tolerate under water stress (Mengel and Arneke, 1982; Lindhauer, 1985).

\subsection{Osmotic potential (-MPa)}

Water is most important to regulate turgidity of the cell, which is essential for cell enlargement and plant growth and development. Osmotic adjustment is more important for plant to maintenance of water absorption under drought stress (Abdelmalek and Khaled, 2011; Chen and Jiang, 2010). The maintenance of turgor by active lowering of osmotic potential ( $\Psi \mathrm{s}$ ) is widely considered as an adaptive trait of plants under water stress environment (Ludlow and Muchow, 1990). The plants exposed to water stress had lower leaf water potential ( $\Psi w)$ as compared with well-watered plants. The ability of crop plant to balance favorable water relations that help to survive under water stress environment (Kaldenhoff et al., 2008; Passioura, 1992).

\section{CONCLUSION AND RECOMMENDATIONS}

Plants have developed molecular, biochemical and physiological approaches to tolerate in the water deficit environment. All six wheat genotypes perform well under normal four irrigation, whereas under drought stress conditions the response of wheat genotypes differ from one another. From current studies, it was found that genetic diversity present between genotypes. It is concluded from present studies based on the different physiological indices including Proline content, Glycine-betaine, Total sugars, Total chlorophyll, Nitrate Reductase Activity ((NRA), Potassium $\left(\mathrm{K}^{+}\right)$content, and Osmotic potential (-MPa) that Khirman, Chakwal-86, MSH-36 and DH-3/48 exhibited drought tolerance and accumulate higher concentration free proline, glycine betaine, total sugars and potassium content, accumulation of these organic and inorganic substances help to maintain osmo-regulation under water stress, moreover higher concentration of these solutes gives advantage tolerate under drought stress meanwhile other wheat genotypes (NIA Amber and NIA-10 10/8 under Terminal drought stress exhibit lower concentration of potassium, glycine-betaine and proline in their leaves under terminal drought environment. It is strongly recommended on the base of current studies that tested genotypes should be included in future breeding programs. 


\section{ACKNOWLEDGE}

The author is highly thankful to Head of Plant Physiology Division, Nuclear Institute of Agriculture (NIA), Tandojam, Pakistan for providing facilities to complete this research.

\section{REFERENCES}

[1] Abdelmalek, C. and T. Khaled. Physiological behavior of wheat genotypes from algerian semi-arid regions grown under salt stress. African J. Agri. Res. 2011; 5:636-641.

[2] Ahmad, M., Z. Akram, M. Munir and M. Rauf. Physio-morphic response of wheat genotypes under rainfed condition. Pak. J. Bot. 2006; 38(5): 1697-1702.

[3] Ahmed, A., Henna, I., and G.M. Chaudhary. Water resources and conservation strategy of Pakistan' paper presented in 23rd Annual General Meeting \& Conference of Pakistan Society of Development Economics, March 12-14, Pakistan Institute of Development Economics, (PIDE Islamabad) 2008. .

[4] Akladious, S. A. Influence of different soaking times with selenium on growth, metabolic activities of wheat seedlings under low temperature stress. African J. Biotech. 2012; 11(82):14792-14804.

[5] Akram N. and A. Hamid. Climate change: A threat to the economic growth of Pakistan Progress in Development Studies January 2015; 15: 73-86

[6] Almeselmani, M., S. Abd Al-rzak, K. Al-zubi, F. Hareri, M. Al-nassan, M. A. Ammar, O. Z. Kanbar, H. Al-Naseef, A. Al-nator, A. Algazawy and H.Abu Al-sael. Physiological Attributes Associated to Water Deficit Tolerance of Syrian Durum Wheat Varieties Exp. Agri. \& Horti., 2012. ; Article ID:19290861, 21-41.

[7] Anonymous. FAO production year book. Rome, Italy. 2000.

[8] Anonymous. Pakistan economic survey 2014-15. Government of Pakistan, finance division, Economic Adviser's Wing, Islamabad. 2014; page 03. PDF file awailable at: http://www.finance.gov.pk/survey/chapters_15/Highlights.pdf

[9] Ashraf MY. Yield and yield components response of wheat (Triticum aestivum L.) genotypes tinder different soil waler deficit conditions. Acta Agron. Hung. 1998. ; 46:4551

[10] Ashraf, M., M. Ozturk, and H. R. Athar. Salinity and Water Stress: Improving Crop Efficiency, Springer, Berlin, 2009; pp 45-50

[11] Ashraf, M.Y., A.R. Azmi, A.H. Khan and S.S.M. Naqvi. Water relations in different wheat (Triticum aestivum L.) genotypes under soil water deficits. Acta Physiol. Plant. 1994; 16: 231-240.

[12] Bates, L.S., R.P. Walden and I.D. Tears Rapid termination of free proline for water stress studies. Plant and Soil. 1973. 39:205-208.

[13] Bohnert HJ, Jensen RG. Strategies for engineering water-stress tolerance in plants. Trends Biotechnol. 1996; 14:89-97. doi: 10.1016/01677799(96)80929-2.

[14] Cao H.X., Sun C.X., Shao H.B., Lei X.T. Effects of low temperature and drought on the physiological and growth changes in oil palm seedlings. African Journal of Biotechnology, 2011; 10: 2630-2637. 
[15] Chen TH, Murata N. Glycinebetaine: an effective protectant against abiotic stress in plants. Trends Plant Sci. 2008;13:499-505. doi: 10.1016/j.tplants..06.007.i: 10.1016/S13695266(02)00255-8.

[16] Chen TH. and N. Murata Enhancement of tolerance of abiotic stress by metabolic engineering of betaines and other compatible solutes. Curr Opin Plant Biol. 2002; 5:250-7.

[17] Chen, H.C.H. and G.J.J. Jiang. Osmotic adjustment and plant adaptation to environmental changes related to drought and salinity. Environ. Rev. 2010; 18:309319.

[18] Delauney A.J., Verma D.P.S. Proline biosynthesis and osmoregulation in plants, The Plant Journal, 1993; 4: 215-223.

[19] Errabii T., Gandonou C.B., Essalmani H., Abrini J., Idaomar M., Skalisenhaji N. Growth, proline and ion accumulation in sugarcane callus cultures under droughtinduced osmotic stress and its subsequent relief. African Journal of Biotechnology, 2006; 5: $1488-1493$.

[20] Farooq, M., A. Wahid and D.J. Lee. Exogenously applied polyamines increase drought tolerance of rice by improving leaf water status, photosynthesis and membrane properties. Acta Physiol. Plant. 2009; 31:937-945.

[21] Flowers, T.J., Yeo, A.R. Ion relations of plants under drought and salinity. Aust. J. Plant Physiol., 1986.; 13, 75-91.

[22] Ghasempour, H.R., D.F. Gaff, R.P.W. Williams and R.D. Gianello. Contents of sugars in

[23] leaves of drying desiccation tolerant flowering plants, particularly grasses. Plant Growth Reg. 1998; 24:185-191.

[24] Gomez, A. K., and A. A. Gomez. Statistical procedures for agricultural research. (2nd edition). John Wiley and Sons. New York. 1984.

[25] Grieve, C.M. and S.R. Gratan. Rapid assay for determination of water soluble Quaternary ammonium compounds. Plant and Soil., 1983; 70: 303-307.

[26] Harmeling, S., and Eckstein, D., Global Climate Risk Index 2013: who suffers most from extreme weather events? Weather-related loss events in 2011 and 1992 to 2011. Germanwatch: 2013; A briefing paper. At http://germanwatch.org/en/download/7170. pdf

[27] Huber SC, Bachmann M, Huber JL. Posttranslational regulation of nitrate reductase activity: a role for $\mathrm{Ca}^{2+}$ and 14-3-3 proteins. Trend Plant Sci. 1996; 1:432-438.

[28] Iqbal, N., M. Ashraf and M. Y. Ashraf. Glycinebetain, an osmolyte of interest to improve water stress tolerance in sunflower (Helianthus annuus L.): water relation and yield. South Afr. J. Bot. 2008; 74: 274-281.

[29] Iturbe, O.I., P.R. Escuredo, C. Arrese-Igor and M. Becana. Oxidative damage in pea plants exposed to water deficit or paraquat. Plant Physiol. 1998; 116:173-181.

[30] Kaiser WM, Spill D, Glaab J. Rapid modulation of nitrate reductase in leaves and roots: indirect evidence for the involvement of protein phosphorylation/dephosphorylation. Physiol Plant. 1993; 89:557-562.

[31] Kaldenhoff, R., M. Ribas-Carbo and J. Flexas et al. Aquaporins and plant water balance. Plant Cell Environ. 2008. 31:658-666.

[32] Kameli, A. and D.M. Losel, Carbohydrates and water status in wheat plants under water stress. New Phytol. 1993; 125: 609-614.

[33] Lichtenthaler, H.K. Chlorophyll and carotenoids pigments of photosynthetic biomembranes. Methods Enzymol., 1987;148: 350-382 
[34] Lindhauer, M.G. Influence of $K$ nutrition and drought on water relations and growth of sunflower(Helianthus annuus L.) Z. Pflanzenernaehr. Bodenk. 1985; 148, 654-669

[35] Liu, B., Y. Li, X. Liu, C. Wang, J. Jin and S.J. Herbert. Lower total soluble sugars in vegetative parts of soybean plants are responsible for reduced pod number under shading conditions. Aus. J. Crop Sci. 2011; 5(13):1852-1857.

[36] Ludlow, M.M. and R.C. Muchow. A critical evaluation of trait for improving crop yields in water limited environments. Adv. Agron. 1990; 42:107-153.

[37] Marschner, H. Mineral nutrition of higher plants. Academic Press, San Diego. 1995.

[38] Mattioni,c. Water and salt stress-induced alterations in proline metabolism of triticum durum seedlings. Physiol. Plant. 1997; 101: 787-792.

[39] Mengel, K. and W.W. Arneke. Effect of potassium on the water potential, the pressure potential, the osmotic potential and cell elongation in leaves of Phaseolus vulgaris. Plant Physiol. 1982; 54: 402-408.

[40] Minocha R, Majumdar R, Minocha SC. Polyamines and abiotic stress in plants: a complex relationship. Frontiers in Plant Science. $2014 ; \quad 5: 175$ doi: 10.3389/fpls.2014.00175. pmid:24847338

[41] Moaveni, P., Effect of water deficit stress on some physiological traits of wheat (Triticum aestivum L.). Agric. Sci. Res. J., 2011. 1(1): $64-68$.

[42] Mohammadkhani, N. and R. Heidari. Drought induced accumulation of soluble sugars and proline in two maize varieties. West Indies Appl. Sci. J. 2008. 3:448-453.

[43] Moinuddin, Fischer R.A., Sayre K.D., Reynolds M.P., Osmotic adjustment in wheat in relation to grain yield under water deficit environments. Agronomy Journal. 2005; 97, 1062-1071. doi: 10.2134/agronj2004.0152

[44] Monyo, E.S., G. Ejeta and D. Rhodes. Genotypic variation for glycinebetaine in sorghum and its relationship to agronomic and morphological traits. Media 1992; 37: 283286.

[45] Mostajeran, A. and V. Rahimi-Eichi. Effects of drought stress on growth and yield of rice

[46] (Oryza sativa L.) cultivars and accumulation of proline and soluble sugars in Sheath and Blades of Their Different Ages Leaves Agric. \& Environ. Sci., 2009; 5 (2): 264-272.

[47] MOUSTAFA, M.A., L. BOERSMA, and W. E. KRONSTAD Response of four spring wheat cultivars to drought stress. Crop Science, 1996; 36, 982-986.

[48] Nageswara, R.R.C., H.S. Talwar and G.C. Wright. Rapid assessment of specific leaf area and leaf nitrogen in peanut (Arachis hypogaea L.) using chlorophyll meter. J. Agron. Crop Sci. 2001; 189:175-182.

[49] Ommen OE, Donnelly A, Vanhoutvin S, van Oijen M, Manderscheid R. Chlorophyll content of spring wheat flag leaves grown under elevated CO2 concentrations and other environmental stresses within the ESPACE-wheat project. Eur. J. Agron. 1999; 10: 197203.

[50] Passioura, J.B. and S.C. Fry. Turgor and cell expansion: beyond the Lockhart equation. Aust J Plant Physiol. 1992; 19:565-576.

[51] Rampino P., Pataleo S., Gerardi C., Mita G., Perrotta C. Drought stress response in wheat:

[52] Rampino P., Pataleo S., Gerardi C., Mita G., Perrotta C. Drought stress response in wheat: physiological and molecular analysis of resistant and sensitive genotypes. Plant Cell and Environment, 2006. 29: 2143-2152.

[53] Rhodes D., Samaras Y. Genetic control of osmoregulation in plants. In: Stronge K. 
[54] (ed.): Cellular and Molecular Physiology of Cell Volume Regulation. CRC Press, Boca Raton, 1994; 347-361.

[55] Riazi, A., K. Matsuda and A. Arsalan. Water stress induced changes in concentrations of proline and other solutes in growing regions of young barley leaves. J. Exp. Bot., 1985; 36: 17 16-1725.

[56] Safarnejad, A., H. Collin, k.D. Bruce and T. mc neilly . Characterization of alfalfa following in vitro selection for salt tolerance. Euphytica 1996; 92: 55-61.

[57] Serraj, R. and T.R.Sinclair. osmolyte accumulation: can it really help increase crop yield under drought condition: plant cell Environ. 2002; 25:333-341.

[58] Sharpe, R.E. and P. Verslues. Proline accumulation in maize (zea maysL.) primary roots at low water potentials. II. Metabolic source of increased proline deposition in the elongation Zone. Plant Physiol. 1999; 119:1349-1360.

[59] Slavik, B. Methods of studying plant water relations. Springer-Verlag, New York, New York, USA. 1974.

[60] Smirnoff, N. Antioxidant systems and plant response to the environment. In Smirnoff $V$ (ed.), Environment and Plant Metabolism: Flexibility and Acclimation, BIOS Scientific Publishers, Oxford, UK. 1995.

[61] Staden .J.,P.D. Hare and W.A. Cress. Proline synthesis and degradation: a model system for elucidating stress related signal transduction.J.Exp . Bot . 1999; 50 (333): 413-434.

[62] Sym, G.J. Optimization of the in vivo assay conditions for nitrate reductase in barley. J. Sci. Food Agric., 1983; 35: 725-730.

[63] Tan, B. H. and Hollaran, G.M. Variation and collerations of proline accumulation in spring wheat cultivars. Crop sci 1982; 22:459- 462.

[64] Verslues PE, Sharma S. Proline metabolism and its implications for plantenvironment interaction. Arabidopsis Book 2010. 8, 3 doi: 10.1199/tab.0140.

[65] Waggoner, P.E., Agriculture and a climate changed by more carbon dioxide. In: Changing Climate: Report of the Carbon Dioxide Assessment Committee. National Academy Press, Washington, DC, 1983; pp. 383-418.

[66] Weyers, J.D.B. and N.W. Paterson. Plant hormones and the control of physiological processes. New Phytol. 2001; 129:375-407.

[67] Zaharieva, M., E. Gaulin, M. Havaux, E. Acevedo and P. Monneveux. Drought and heat responses in the wild wheat relative Aegilops geniculata Roth: Potential interest for wheat improvement. Crop Science, 2001; 41: 1321-1329.

\section{FIGURE}

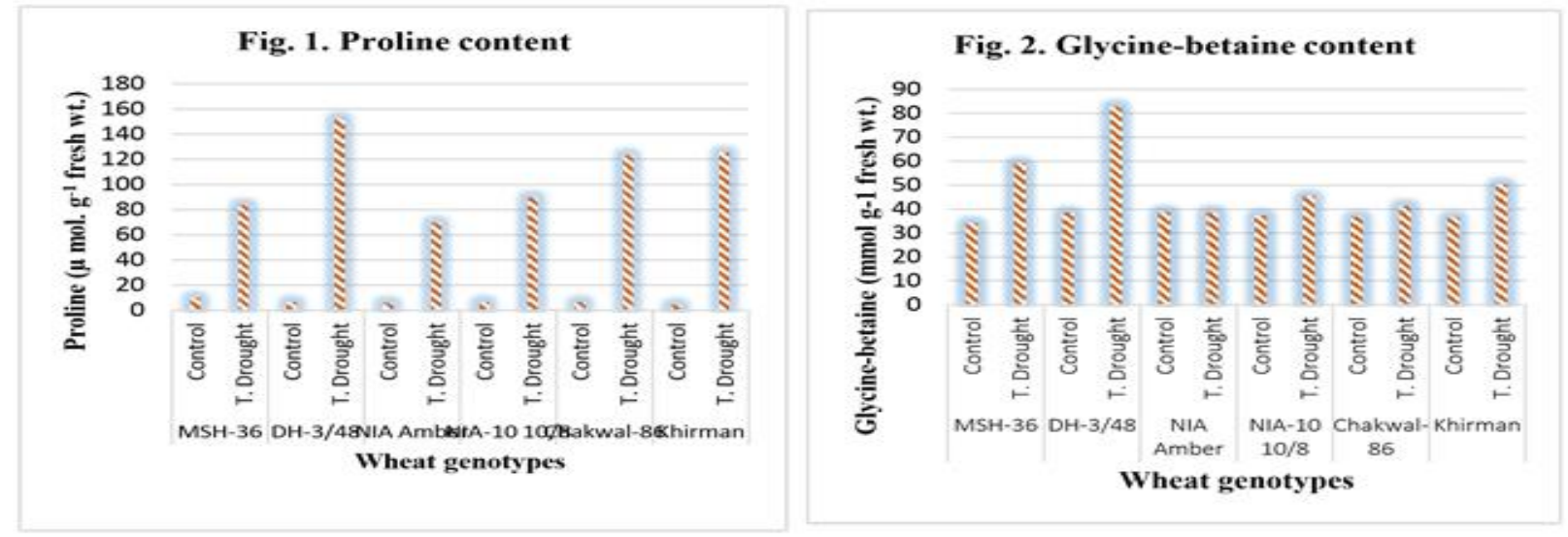



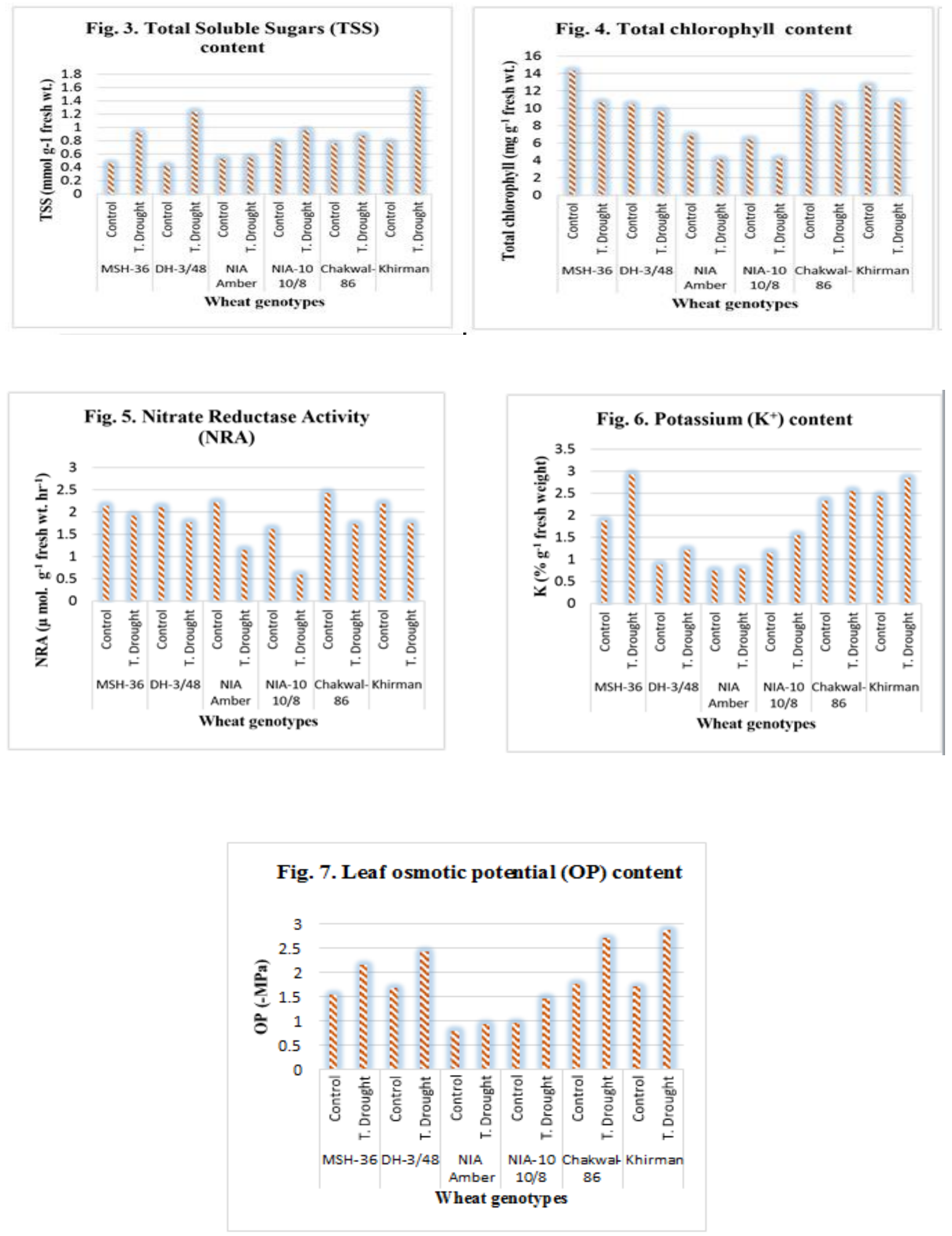